DOE/me/23057. T2

\title{
NOVEL CONCEPT DEVELOPMENT OF AN INTERNAL RECIRCULATION CATALYST FOR MILD GASIFICATION
}

Progress Reportfor the Period June 1, 1988 August 31, 1988

By
R. A. Knight
S. P. Babu
K. A. Martin
S. C. Chao

October 1988

Work Performed Under Contract No.: DE-AC21-86MC230st

For

U.S. Department of Energy

Office of Fossil Energy

Morgantown Energy Technology Center

Morgantown, West Virginia 26505

By

Institute of Gas Technology

Chicago, Illinois 


\section{DISCLAIMER}

This report was prepared as an account of work sponscred by an agency of the United States government. Neither the United States Government nor any agency thereof, nor any of their employees, makes any warranty, express or implied, or assumes any legal liability or responsibility for the accuracy, completeness, or usefulness of any information, apparatus. product, or process disclosed, or represents that its use would not infringo privately owned rights. Reference herein to any specific commercial product, process, or service by trade name, trademark, manufacturer, or otherwise, does not necessarily constitute or imply its endorsement, recommendation, or favoring by the United States Government or any aguncy thereof. The views and opinions of authors expressed herein do not necessarily state or reflect those of the United States Government or any agoncy thereof.

Printed in the United States of America

Available from National Technical Information Service

U.S. Department of Hornmerce 5285 Port Royal Road

Springfield, VA 22161

NTIS price codes

Printed copy: AO1

Microficho copy: $A 01$ 


\section{NOVEL CONCEPT DEVELOPMENT OF AN INTERNAL RECIRCULATION CATALYST FOR MILD GASIFICATION}

Progress Report for the Period June 1,198B-August 31, 1988

By

R. A. Knight

S. P. Babu

K. A. Martin

S. C. Chao

October 1988

Work Performed Under Contract No.: DE-AC21-86M Mepos7

For

U.S. Department of Energy

Office of Fossil Energy

Morgantown Energy Technology Center

P.O. Box 880

Morgantown, West Virginia 26505

By

Institute of Gas Technology

IIT Center, 3424 S. State Street

Chicago, Illinois 60616

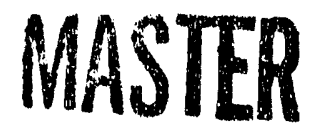




\section{EXECUTIVE SUMMARY}

This report presents the results of work performed between June 1 and August 31,1988 under DOE Contract No. DE-AC21-86MC23057. The objective of this program is to provide an overall evaluation of a novel process concept for mild gastfication by completing work in three major tasks: 1) LaboratoryScale Experiments, 2) Bench-Scale Tests, and 3) Proof-of-Concept Testis and Evaluation (optional).

During this quarter, experimental work involving potential reclrculating catalysts for coal, Inttlated in the previous quarter, was continued. The construction and shakedown of an all quartz laboratory-scale isothermal Ereefall reactor was completed. Three free-fall experiments were performed in an existing stalnless-steel free-fall reactor with untreated and ammonta treated Illinols No. 6 high-volatile bituminous coal, and the analyzed data are presented hereln.

A survey of available literature on catalyzed devolatilization of coal, coal pretreatment methods, and related topics was made. Based on the results of thls survey, two potential reclrculating catalysts, in addition to the already selected zinc chloride, were selected for study: ferrous chloride $\left(\mathrm{FeCl}_{2}\right)$ and ferrlc chlorlde $\left(\mathrm{FeCl}_{3}\right)$. Also, based on the survey, two coal pretreatment/chemical cominution methods were selected for study, in addition to methanol treatment: ammonia and n-butylamine pretreatment. A matrix of expertments was formulated to study the three catalysts and three pretreatment methods selected. 


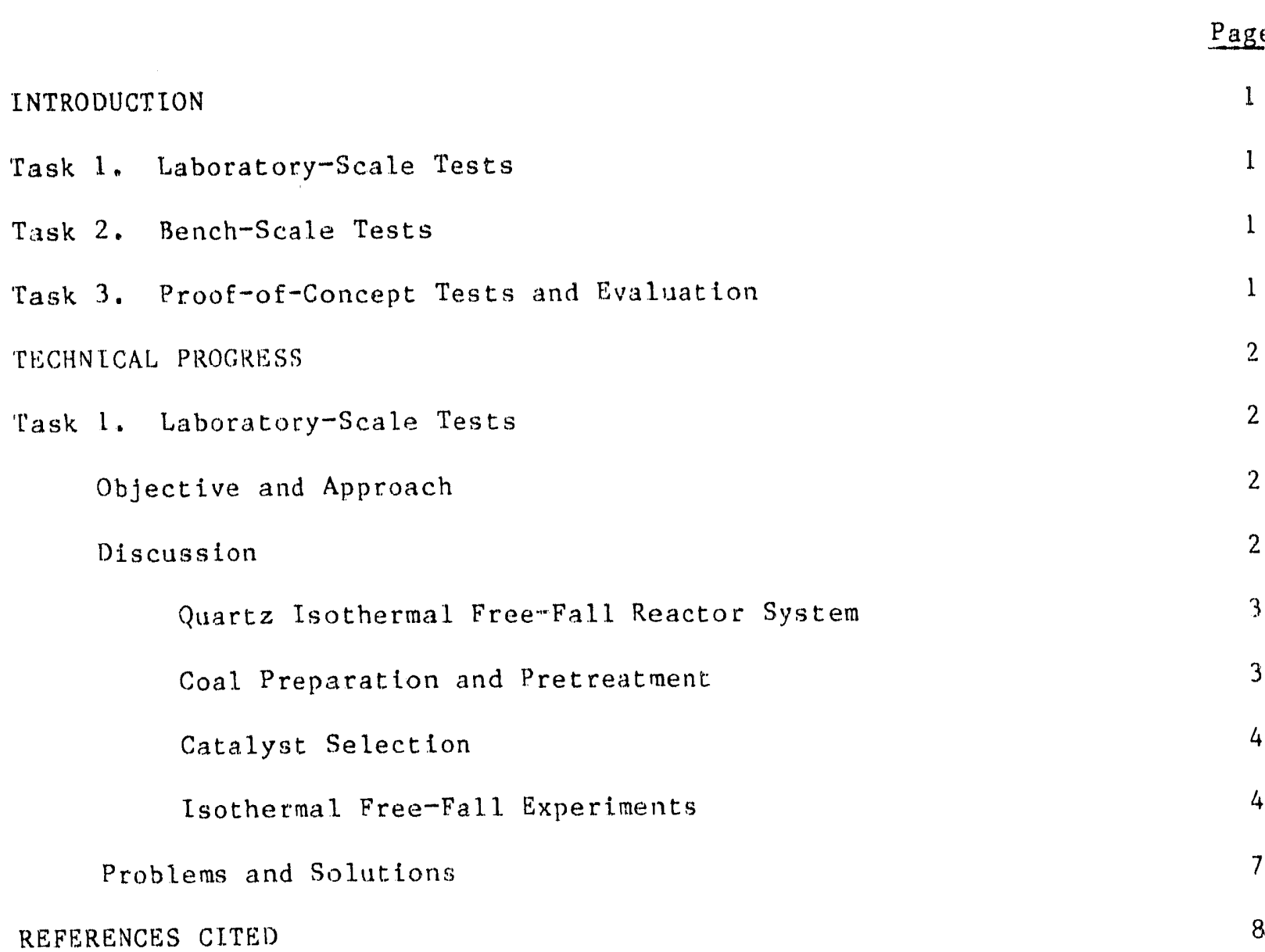

age 


\section{LIST OF TABLES}

Table No.

Page

1

Analysis of Feed Coal Samples

5

Results of Isothermal Free-Fall Devolatilization

Experiments

vii

1

OF

G A S

TECHNOLOG Y 


\section{INTRODUCTION}

The goal of this program is to evaluate a novel process concept for mild gasification of coal using an internal recirculating catalyst. This report describes progress during the elghth quarter of the program. The work is divided into three major tasks:

1. Laboratory-Scale T'ests

2. Bench-Scal.e Tests

3. Proof-of-Concept Tests and Evaluation (optional).

The objectives of the individual tasks are described below.

Task 1. Laboratory-Scale Tests

The objective of this task is to obtain detalled information on the effects of the selected internal recirculation catalyst on the products of mild coal gasification using a pyrolysis-gas chronatograph (PY-GC) system. Three different types of coals (Illinois No. 6, Wyodak subbituminous, and North Dakota lignite) are to be tested. The effects of operating condittons on product quality are to be investigated.

\section{Task 2. Bench-Scale Tests}

The objective of this task is to conduct larger-scale tests than those of Task 1 to determine the effects of the catalyst on the products of mild coal gasification. These tests will be conducted with a selected test coal in existing experimental equipment.

Task 3. Proof-of-Concept Tests and Evaluation

The objective of this task, which is subject to the approval of DOE/METC to proceed, is to conduct large-scale testing of the effect of the internal recirculation catalyst on mild coal gastfication and process design and economic studies. These large-scale tests are to be conducted in an existing 8-inch-diameter gaslfier. 


\section{TECHNICAL PROGRESS}

\section{Task 1. Laboratory Scale Testo}

\section{Objective and Approach}

The objective of this task is to obtain detalled information on the effects of the selected internal recirculation catalyst of the products of mild coal gastefcation under various reaction conditions, by means of experiments conducted in laboratory-scale pyrolysis equipment. Three different types of coals (I11inois No. 6, Wyodak subbitumtnous, and North Dakota lignite) are to be tested.

All work performed during this reporting period was under Subtask 1.2 , Laboratory-Scale Catalytic Coal Devolatilization Tests.

\section{Discussion}

In the previous technical progress report for the period of June through August of 1988, a quartz tube 1sothermal free-fall. reactor system destgn was described, and the initiation of its construction was reported. The first of three free-fall experiments in an existing stainless-steel free-fall reactor, using uncatalyzed coal, was conducted during the previous quarter.

The construction of the quartz free-fall reactor proceeded to completion during this reporting period. The calibration of system components has also been done, and system shakedown is completed.

A survey of available literature on catalyzed coal devolatilization, coal pretreatment methods, and related topics was made. Based on the results of this survey, two potential zecirculating catalysts were selected for study in addition to zinc chloride $\left(\mathrm{ZnCl}_{2}\right)$ : ferrous chloride $\left(\mathrm{FeCl}_{2}\right)$ and ferrtc chloride $\left(\mathrm{FeCl}_{3}\right)$. Also, based on the survey, two coal pretreatment/chemical comminution methods were selected for study, in addition to methanol treatment: ammonia and n-butylamine pretreatment. A matrix of experiments was formulated to study the three catalysts and three pretreatinent methods selected.

During this reporting period, three isothermal free-fall experiments were also conducted in the existing stainless-steel reactor, using untreated, methanol-treated, and ammonia-treated IIIInois No. 6 bituminous coal. 


\section{Quartz Isothermal Free-Fall Reactor Systern}

The new quartz reactor system has been descrlbed in detall in the previous quarterly report. No major changes were made to the design. The support structures and glassware were assembled and leak tested; minor modiffcations were made to ensure laak tight operation. Caltbrations of the seven thermocouple tnputs to the temperature recorder, dry test meter, coal feeding system, Inlet gas rotameters, and on-line Infrared co monitor were accomplishid.

\section{Coal Preparation and Pretreatinent}

Illinols No. 6 high-volatlle bituminous coal received from the Peabody Coal Company Randolph Prep Plant has been prepared for use in the quartz freefall reactor. The coal was crushed in a jaw crusher and pulverized in a ringand-puck mill while wet, then wet-screened to $-100+200$ mesh. The stzed, wet coal was then dried in a $140^{\circ} \mathrm{F}$ oven under inert atmosphere, followed by vacuum drying overnight at the same temperature. The dried coal was then riffled down to approximately 120-gram samples for storage under nitrogen at partial vacuum.

An examination of current literature sources has resulted in the selection of two coal pretreatment method to be included in the laboratoryscale experimental program in addition to methanol treatment: pretreatment with liquid ammonia and liquid n-butylamine. These treatments have been reported to swell coal, enhancing its porosity, bringing about limited comminution, and posstbly increasing conversion ylelds. ${ }^{2}, 2$

The following ammonia pretreatment method, modified from a procedure published by llatida et a1.,' was used for one of the free-fall experiments performed during the reporting period. Coal was charged into a clean, dry stainless-steel bomb, which was then pressurized and depressurized repeatedly with nitrogen, and finally evacuated. The vessel was then immersed in dry ice, and ammonia vapor from a lecture bottle was introduced and allowed to condense in the vessel. After 20 minutes, the sample vessel was sealed and heated to $572^{\circ} \mathrm{F}\left(300^{\circ} \mathrm{C}\right)$, which resulted in an ammonia pressure of $400 \mathrm{psig}$. The bomb was maintalned at these conditions for 3 hours, then cooled, depressurlzed through a sulfuric acid scrubber, and purged with nitrogen to 
remove residual ammonia. The treated sample was vacuum- ${ }^{-1}$ ried for 8 hours at $113^{\circ} \mathrm{F}\left(45^{\circ} \mathrm{C}\right)$ prior to use in free-fall experiments.

Treatment of coal with n-butylarnine will be performed in a modification of the procedure described by Green and West. ${ }^{2}$ The coal sample will be immersed in solvent at its atmospheric bolling polnt, $172^{\circ} \mathrm{F}$, for 3 hours. The solvent will then be removed by vacuurn at room temperature.

\section{Catalyst Selection}

The survey of literature also resulted in a selection of two additional potential Lewis-acld catalysts, ferrous chloride and ferric chloride. These substances will be tested, along with zlnc chloride, as catalysts for the devolatilization of Illinois No. 6 bituminous coal. The catalysts will be impregnated on the coal from aqueous solution by evaporation of the water under reduced pressure in an inert atmosphere at ambient temperature. The catalyst concentration in all cases will be $10 \%$ by welight of coal.

\section{Isotherma1 Eree-Fal1. Experiments}

To establish base-line operating data with uncatalyzed samples of the Illinots No. 6 coal recelved from the Peabody Coal Company Randolph Preparation Plant, a series of experiments was scheduled for the existing 1.5-inch ID stainless-steel isothermal free-fall reactor. Three experiments were performed during the report period, one with untreated coal, one with methanol-treated coal, and one with ammonitreated coal. In all three of the experiments, wet-crushed, wet-screened $-100+200$ mesh coal was devolatilized under helium atmosphere.

Table 1 shows the analyses of the feed coals used in the three free-fall experiments. Table 2 shows the complete analyzed data from the experiments. The data in Table 2 indicate that there are no rajor observed differences in the devolatilization ylelds and carbon conversion between untreated and methanol-treated coal, but ammonia treatment may increase the overall carbon conversion. As noted in the table footnotes, there was not suffictent steadystate gas composition data in experiment RC-062188 (ammonia-treated coal) to produce a reliable gas yield; thus no attempt was made to calculate relative gas and condensible yields. Experiments in the quartz reactor with ammoniatreated coal will be required to vertfy the increased carbon conversion and determine the selectivity to gases and condenstbles. 


\section{Table 1. ANALYSIS OF FEED COAL SAMPLES}

Coal Type: Illinols No. 6 high-volatile bituminous

Source: Peabody Coal Company, Randolph Prep. Plant

Analysis

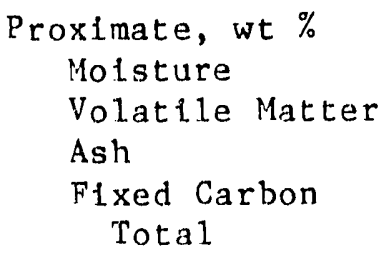

\section{Untreated}

MeOH-Treated

$\mathrm{NH}_{3}$-Treated

\begin{tabular}{rrr}
6.27 & 4.12 & 1.98 \\
37.08 & 37.65 & 37.22 \\
6.87 & 7.22 & 7.94 \\
49.78 & 51.01 & 52.86 \\
\hline 100.00 & 100.00 & 100.00
\end{tabular}

\begin{tabular}{r}
79.03 \\
5.47 \\
3.58 \\
1.82 \\
10.09 \\
\hline 100.00 \\
13,128
\end{tabular}

78.99

5.28

3.63

1.85

10.25

100.00

13,071

12,844

The data on the nature of the condenstbles from these experiments reveal some interesting differences; both the methanol and ammonia treatments are observed to effect an increase in 1 lght oil content along with a decrease in the amount of phenollcs and naphthalene. In all cases, however, $84 \%$ to $88 \%$ of the condenstble co-product falls into the range of middle oils to pitch.

For the quartz isothermal free-fall reactor, a matrix of experiments was formulated, based on the examination of these three pretreatment methods and three catalysts. Following is a list of process parameters to be studied:

- Reactor temperature $\left(1000^{\circ}, 1250^{\circ}, 1500^{\circ} \mathrm{F}\right)$

- Coal pretreatment method (none, methanol, ammonia, N-butylamine)

- Catalyst (none, $\mathrm{ZnCl}_{2}, \mathrm{FeCl}_{2}, \mathrm{FeCl}_{3}$ )

- Gas atmosphere $\left(\mathrm{N}_{2}, \mathrm{~N}_{2} /\right.$ steam, ${ }^{*} \mathrm{CO}_{2}$, synthesis gas $\left.{ }^{* *}\right)$

\footnotetext{
* $20 \%$ steam.

** $50 \% \mathrm{~N}_{2}, 15 \% \mathrm{H}_{2}, 5 \% \mathrm{CO}_{2}, 11 \% \mathrm{CO}, 14 \% \mathrm{CH}_{4}, 3 \% \mathrm{C}_{2} \mathrm{H}_{4}$, and $2 \% \mathrm{C}_{2} \mathrm{H}_{4} \cdot$
} 
Table 2. RESULTS OF ISOTHERMAL FREE-FALL DEVOLATILIZATION EXPERIMENTS

Coal Type: Illinols No. 6 high-volatile bituminous Source: Peabody Coal Company, Randolph Prep. Plant

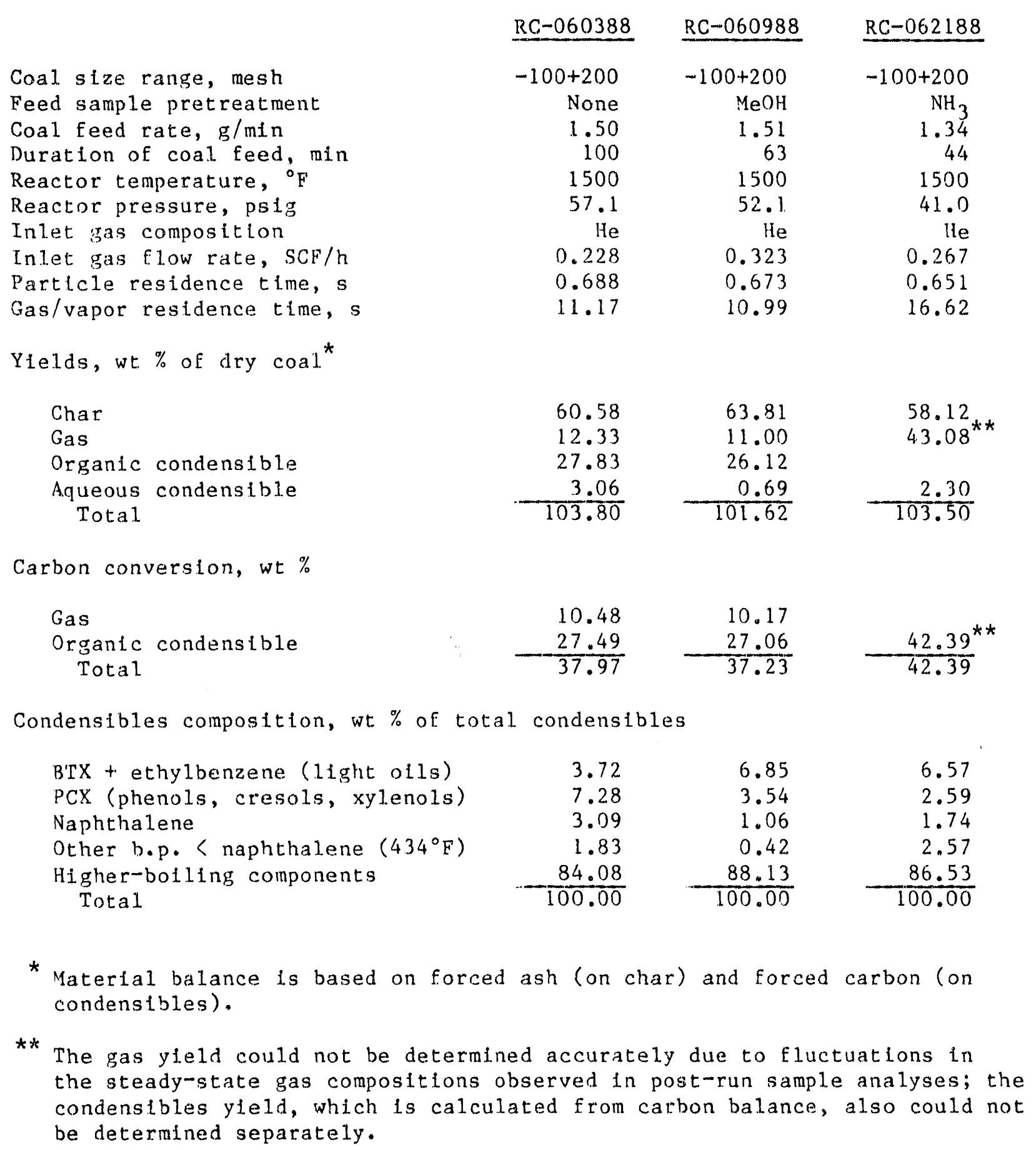


Reactor pressure w111 be held below 5 psig; partlcle resldence time will be held at 0.50 secouds for all experiments.

\section{rroblerns and Solutions}

In the experfment with the ammonlatreated coal sample, the reactor pressure fluctuated erratically. This resulted $1 \mathrm{n}$ unsteady product gas flow and consequent unrellabllity of gas composition data. This was noted in the data presented in Table 2. The char ylelds and composttion were unaffected, and partial matertal lalance data were acquiced. However, the data frorn this experinent should be corroborated by further tests with ammonia-treated coal before any conclusions are presented.

An Inttal shakedown test of the quartz free-fall reactor system with Illinols No. 6 bltuminous coal, ustng only the star feeder, resulted in plugging of the reactor with agglomerated char. It was determined that the plugglng was due to excesslve pulsing in the cnal feed under the test condftions, leading to bursts of coal into the reactor which swelled and agglomerated so rapidly as to block the entire reactor. This problem was addressed by lnstalling the dual-feeder setup whereby the feed is metered by a screw feeder and dumped into the reactor wh th the star feeder running lean at a htgher speed. This arrangement results in a ruch more uniform feed.

An Inablifty to pump methylene chloride solvent into the char recelver: vessel was traced to vapor lock in the solvent pump head, due to the unusually hot weather in the Chicago area. This problem was solved by cooling the pump head with dry ice.

It was discovered that a 1/4-inch glass stub, which served as an inlet for solvent to the top of the char filter as well. as a port for one of the reactor thermocouples, was excessively fragile under torque necessary to seal the joint with a compression fitting. After two incidences of breakage, the filter top was rebuilt, fncorporating an extra ball jotnt at that point, which proved satisfactory in preventing a torque stress on the stub. 
1. Matida, M., Nishtyama, Y. and Tamal, Y., "Gastflcation of Coals Treated With Nonaqueous Solvents. 1. Liquid Ammonia Treatment of a Bituminous Coal", Fue1 56 4, 177-180 (1977).

2. Green, T. K., and West, T. A., "Coal Swelling in n-Amlnes and n-Alcohols," ACS D1y. of Fuel Chen. "orepr.2 30 4, 488-492 (1985).

7WP/RPP/61086qr 


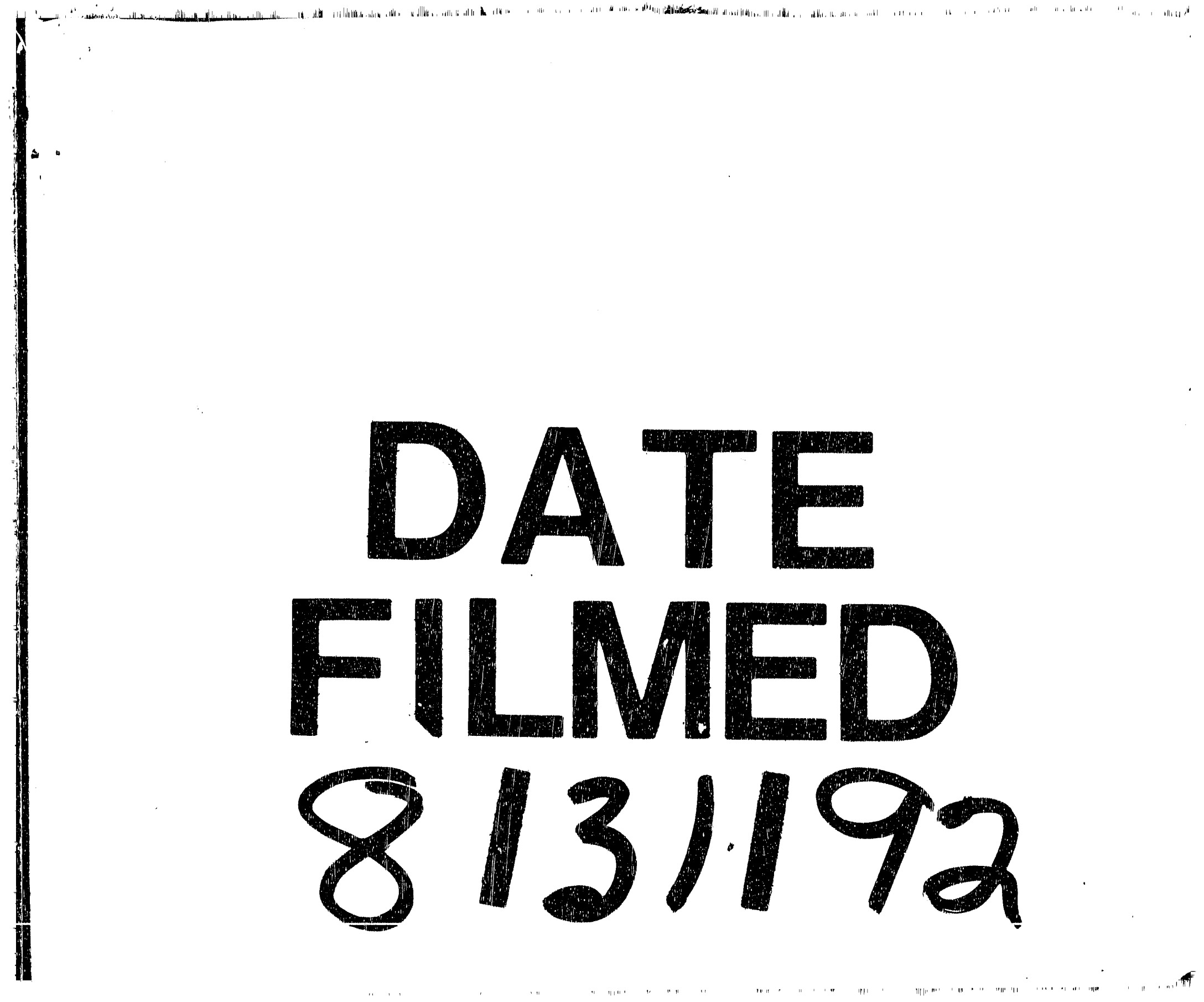


